\title{
STKIP WIDYA YUWANA MADIUN MENUJU KAMPUS MERDEKA BELAJAR DENGAN PENGEMBANGAN MODEL PEMBELAJARAN BERBASIS MOTIVASI ARCES (ARCES BASED OF MOTIVATIONAL)
}

\author{
Andreas Kosasih \\ STKIP Widya Yuwana \\ kosas_ih@yahoo.com
}

\begin{abstract}
Learning skills are really needed by students/university students, in academic and non-academic environments. From the results of observations in the field of the implementation of learning, it is known that the process and learning outcomes have not been maximized. The author argued, good learning models and presentations are models and presentations of learning that not only stimulate metacognition but are also able to stimulate meta-psychomotor and also meta-affection of students/university students. The availability of ARCES Motivation Based learning models for students/university students able to improve the ability of students/university students. To develop a curriculum, syllabus and Semester Learning Plan/Lesson Plan is not difficult if adequate and relevant learning models are available in the field so that the teacher/lecturer can develop effective learning. The availability of various guidebooks will provide references and implications for teachers/lecturers, so that learning is more varied, fun and not boring and effective in achieving learning objectives.
\end{abstract}

Keywords: STKIP Widya Yuwana Madiun, independent learning, model development, ARCES motivation.

\section{PENDAHULUAN}

Perkembangan informasi dan teknologi yang kian pesat tidak dapat dihindari dan menjadi bagian penting dari pendidik dan pembelajaran. Pendidik (guru dan dosen) sebagai garda terdepan dunia pendidikan harus paham teknologi, mengikuti perkembangan terkini, serta menyesuaikan dan memanfaatkannya dalam pembelajaran (Abdul Muis Joenaidy, 2019: 12). Hal ini penting mengingat 
pembelajaran yang berkembang saat ini hampir dipastikan memanfaatkan teknologi didalamnya. Pembelajaran sudah tak terbatasi oleh ruang dan waktu. Pembelajaran dapat dilakukan dimanapun, kapanpun, serta tidak mengenal jarak. Oleh sebab itu revolusi pembelajaran menjadi suatu keniscayaan.

Inovasi pembelajaran di era revolusi industri 4.0 selain menguasai teknologi, para guru dan dosen antara lain perlu menekankan peentingnya pada penguasaan teori, materi, metode, media, strategi, pendekatan, model dan pengembangan motivasi serta penilaian pembelajaran. Dari kesekian hal yang perlu dikuasai guru dan dosen seperti diatas, yang agak terabaikan adalah penguasaan mengenai mengenai pengembangan model pembelajaran dan pengembangan motivasi.

STKIP Widya Yuwana Madiun sebagai lembaga tinggi yang bernaung di bawah Direktorat Jenderal Pendidikan Timggi Kementerian Pendidikan dan kebudayaan tertantang untuk mengembangkan diri sebagai kampus medeka belajar. Dengan harapan utnuk semakin menjadi kampus yang otonom dengan kultur pembelajaran yang inovatif dan fleksibel.

Untuk memenuhi tuntutan sebagai kampus otonom dengan kultur pembelajaran yang inovatif dan fleksibel diperlukan kajian, baik itu kajian teori maupun kajian implementasi di lapangan. Tentunya teori dan praktik pembelajaran dari berbagai sumber yang tersedia dan yang sungguh mampu membuat kultur pembelajaran yang inovatif dan fleksibel, sehingga kualitas proses dan hasil pembelajaran menjadi lebih baik.

Guru/dosen merupakan komponen yang sangat menentukan keberhasilan suatu pendidikan, karena guru merupakan figur sentral dalam pembelajaran. Meskipun paradigma baru menggeser teacher centered menjadi student centered bukan berarti peran dan tugas guru dalam pembelajaran berkurang (Das Salirawati, 2018: 3). Guru tetap pegang peranan untuk menentukan keberhasilan pembelajaran, terutama terkait dengan proses pembelajaran, karena kreativitas guru sangat diperlukan untuk menstranfer ilmu pengetahuan dan menggali potensi peserta didik. Oleh karena peran dan tugasnya sangat penting, guru dituntut untuk berupaya meningkatkan kualitas dan kinerjanya agar berdampak pada peningkatan kualitas pendidikan.

Selain hal-hal di depan, kurangnya perhatian terhadap kualitas kemampuan siswa/ mahasiswa sampai saat ini dapat dilihat antara lain dari kurangnya upaya mengembangkan model serta pemberian motivasi pembelajaran yang tepat. Pola pengembangan model dan motivasi yang dikembangkan guru/dosen tidak terlepas dari kualitas dosen dan perencanaan program yang dipersiapkan.

Menurut Andreas Kosasih, dkk (2013) salah satu penerapan dan pengembangan sistem motivasi itu adalah model ARCES yaitu: attention (perhatian), relevance (relevan), confidance (percaya diri), enjoyment (rasa 
senang) dan satiscaftion (kepuasan) yang disingkat dengan model ARCES (ARCES Models). Dosen dalam proses pembelajaran dapat menerapkan dan mengembangkan prinsip-prinsip motivasi ini dengan tujuan untuk merangsang, membangkitkan, meningkatkan dan memelihara motivasi mahasiswa.

Dari paparan di atas dapat dirumuskan secara singkat alasan mendasar yang menjadi latar belakang penulisan makalah ini, yaitu sebagai berikut.

1. STKIP Widya Yuwana Madiun yang salah satu misinya (misi pertama): menguasai teori atau konsep secara benar berkaitan dengan Ilmu Pendidikan Teologi dan mengembangkannya perlu diaktualisasikan.

2. Memperhatikan harapan dari Kementerian Pendidikan dan Kebudayaan STKIP Widya Yuwana Madiun perlu menjadi kampus Merdeka belajar/kampus merdeka dengan ciri belajar di yang lebih otonom dengan kultur pembelajaran yang inovatif dan fleksibel.

3. Belum tersedianya model pembelajaran berbasis motivasi ARCES (ARCES Based of Motivational) untuk untuk guru/dosen/mahasiswa/siswa, yang diharapkan dapat menjadi rujukan dan alternatif pilihan dosen dalam rangka meningkatkan kualitas proses dan hasil pembelajaran.

Oleh sebab itu gagasan: STKIP Widya Yuwana Madiun Menuju Kampus Merdeka Belajar dengan Mengembangkan Model Pembelajaran Berbasis Motivasi ARCES (ARCES Based of Motivational) nantinya akan memberikan kontributif sebagai alternatif dan variasi, terutama apabila dosen ingin merangsang, menumbuhkan, meningkatkan motivasi dan membuat siswa senang (enjoy) melakukan kegiatan belajar.

\section{PEMBAHASAN}

Judul Materi seminar ini adalah STKIP Widya Yuwana Madiun Menuju Kampus Merdeka Belajar dengan Mengembangkan Model Pembelajaran Berbasis Motivasi ARCES (ARCES Based of Motivational), oleh sebab itu berturut akan diuraikan mengenai: STKIP Widya Yuwana, kampus merdeka belajar, model pembelajaran, dan motivasi ARCES.

1. STKIP Widya Yuwana

STKIP Widya Yuwana Madiun adalah lembaga pendidikan yang bernaung dibawah Direktorat Jenderal Pendidikan Tinggi Kementerian Pendidikan dan Kebudayaan RI yang didirikan untuk mendidik tenaga awam yang berkecimpung dalam bidang keagamaan dan sosial, dengan visi "Unggul dan Kontekstual”. Sedangkan Misi: (a) Menguasai teori atau konsep secara benar berkaitan dengan Ilmu Pendidikan Teologi dan mengembangkannya. (b) Mengembangkan pembinaan yang berorientasi pada kedewasaan pribadihidup beriman-semangat merasul dan terlibat dalam hidup masyarakat. (c) 
Mengembangkan kemampuan untuk mengenali, menganalisis dan menanggapi berbagai permasalahan/kebutuhan gereja dan masyarakat melalui ilmu metodologi pendidikan dan analisa sosial. (d) Mengembangkan ketrampilan untuk mengaplikasikan dan mengimplementasikan teori dan konsep secara benar dan kontekstual dalam rangka pengabdian/pelyanan kepada masyarakat sesuai dengan bidang keahlian yang dimiliki. (e) Mengembangkan kerjasama dengan berbagai lembaga dalam rangka pengembangan kependidikan, karya katekese, penelitian, dan pengabdian masyarakat (http://widyayuwana.ac.id).

2. Kampus Merdeka Belajar

Yang dimaksud dengan merdeka belajar/kampus merdeka adalah belajar di perguruan tinggi yang lebih otonom. Prinsipnya perubahan paradigma pendidikan agar menjadi lebih otonom dengan kultur pembelajaran yang inovatif. Dengan pelaksanaannya mendorong proses pembelajaran yang semakin otonom dan fleksibel. Hal tersebut bertujuan demi tercapainya kultur/budaya belajar yang inovatif, tidak mengekang, dan sesuai dengan kebutuhan masing-masing perguruan tinggi (Kementerian Pendidikan dan Kebudayaan: 2019: 10). Merdeka belajar memiliki makna bahwa: unit pendidikan (sekolah, guru dan muridnya) mempunyai kebebasan untuk berinovasi, belajar dengan mandiri, dan kreatif. Sehingga, seluruh anak didik Indonesia memilik ragam cara belajarnya masing-masing.

3. Model Pembelajaran

Akhir-akhir ini belajar dan pembelajaran disikapi secara personal sebagai proses dan upaya peserta didik yang bersifat self learning dan self change dengan pengoptimalkan kemampuan dan kapasitas diri serta sumber daya lingkungan (Eny Nur Aisyah, dkk. 2019: 1). Pembelajaran bukan sekadar transfer pengetahuan (transfer of knowledge), melainkan juga merupakan transfer belajar (transfer of learning) yang mampu menghasilkan perubahan pola pikir dan pola bertindak yang dapat diimplementasikan dalam kehidupan nyata. Oleh sebab itu aktivitas belajar harus terkoneksi dengan kehidupan nyata. Peserta didik harus terus didorong untuk berpikir kritis (critical thinking) terhadap berbagai isu dan peristiwa yang muncul di lingkungannya.

Model dapat diartikan sebagai suatu bentuk tiruan (replika) dari benda yang sesungguhnya, sehingga memiliki bentuk atau konstruksi yang sama atau mirip dengan benda yang dibuatkan tiruannya atau contohnya. Model juga dapat ditafsirkan sebagai suatu contoh konseptual atau prosedural dari suatu program, sistem, atau proses yang dapat dijadikan acuan atau pedoman dalam rangka 
memecahkan suatu masalah atau mencapai suatu tujuan (Sri Sulisyorini, 2007: 13).

Kata pembelajaran merupakan terjemahan dari “instruction”, yang banyak di pakai dalam dunia pendidikan Amerika Serikat. Istilah ini banyak dipengaruhi oleh aliran psikologi kognitif holistik, yang menempatkan siswa sebagai pusat kegiatan pembelajaran (Wina Sanjaya, 2008: 102). Dari beberapa uraian di atas, maka semakin jelas bahwa istilah pembelajaran (instruction) itu menunjuk pada usaha siswa mempelajari materi ajar sebagai akibat perlakuan dari guru sebagai pengajar.

Oleh sebab itu hakikat model pembelajaran adalah sebuah sistem proses pembelajaran yang utuh mulai dari awal hingga akhir. Model pembelajaran melingkupi: pendekaran pembelajaran, strategi pembelajaran, metode pembelajaran dan teknik pembelajaran (Munif Chatib, 2019: 4). Model pembelajaran adalah bentuk pembelajaran yang tergambar dari awal sampai akhir yang disajikan secara khas oleh guru. Dengan kata lain model merupakan bungkus atau bingkai dari penerapan suatu metode, pendekatan, strategi, teknik/taktik pembelajaran.

Untuk mengetahui kualitas model pembelajaran harus dilihat dari dua aspek, yaitu proses dan produk. Aspek proses mengacu apakah pembelajaran mampu menciptakan sitausi belajar yang menyenangkan (joyful learning) serta mendorong siswa untuk aktif belajar dan berpikir secara kreatif. Sementara itu aspek produk mengacu apakah pembelajaran mampu mencapai tujuan, yaitu meningkatkan kemampuan siswa sesuai dengan standar kemampuan atau kompetensi yang ditentukan. Dalam hal ini sebelum melihat hasilnya, terlebih dahulu aspek proses sudah dapat dipastikan berlangsung secara baik.

Joyce dan Weil (2000: 1) menyatakan bahwa: "Models of teaching are really models of learning. As we help student acquire information, ideas, skills, value, ways of thingking and means of expressing themselves, we are also teaching them how to learn”. Hal ini berarti bahwa model mengajar merupakan model belajar dengan model tersebut guru dapat membantu siswa untuk mendapatkan atau memperoleh informasi, ide, keterampilan, cara berpikir, dan mengekspresikan ide diri sendiri. Selain itu, mereka juga mengajarkan bagaimana mereka belajar.

\section{Motivasi ARCES}

\section{a. Pengertian Motivasi}

Motivasi merupakan jantungnya proses pembelajaran. Oleh karena itu, motivasi begitu penting dalam proses pembelajaran, maka tugas guru dan dosen yang pertama dan terpenting adalah membangkitkan atau 
membangun motivasi siswa/mahasiswa terhadap apa yang akan dipelajari oleh siswa.

Sebenarnya, apa itu motivasi? Menurut KBBI (Kamus Besar Bahasa Indonesia), motivasi adalah dorongan yang timbul pada diri seseorang secara sadar atau tidak sadar untuk melakukan suatu tindakan dengan tujuan tertentu. Dapat dikatakan motivasi adalah suatu energi penggerak, pengarah dan memperkuat tingkah laku. Motivasi sendiri terbagi dua, yaitu motivasi intrinsik dan ekstrinsik. Motivasi intrinsik adalah motivasi yang timbul dari dalam individu untuk berbuat sesuatu. Sedangkan motivasi ekstrinsik adalah motivasi yang timbulnya dari luar individu. Motivasi adalah suatu dorongan atau alasan yang menjadi dasar semangat seseorang untuk melakukan sesuatu untuk mencapai tujuan tertentu. Arti motivasi juga dapat didefinisikan sebagai semua hal yang menimbulkan dorongan atau semangat di dalam diri seseorang untuk mengerjakan sesuatu.

Secara etimologi kata motivasi berasal dari bahasa Inggris, yaitu "motivation", yang artinya "daya batin” atau "dorongan”. Sehingga pengertian motivasi adalah segala sesuatu yang mendorong atau menggerakkan seseorang untuk bertindak melakukan sesuatu dengan tujuan tertentu. Mengenai pengertian motivasi, banyak pakar menguraikan pendapatnya berdasarkan titik penekanan yang berbeda-beda, sesuai dengan hasil kajian yang mereka yakini. Menurut asal katanya, motivasi berasal dari bahasa Latin movere yang berarti menggerakkan. Wlodkowski (1985) dalam R. Angkowo \& A. Kosasih (2007) menjelaskan bahwa motivasi sebagai suatu kondisi yang menyebabkan atau menimbulkan perilaku tertentu, dan yang memberi arah dan ketahanan (persistence) pada tingkah laku tersebut.

\section{b. Fungsi Motivasi dalam Pembelajaran}

"Motivation is an essential condition of learning", yang artinya dalam proses pembelajaran, dalam diri siswa diperlukan adanya motivasi. Hasil belajarnya siswapun banyak ditentukan adanya motivasi. Oleh sebab itu semakin tepat motivasi yang diberikan oleh guru, hasil pembelajaran semakin baik. Sebab motivasi akan menentukan intensitas usaha siswa untuk melakukan sesuatu, termasuk didalamnya melakukan belajar. Oleh sebab itu Nasution (2000: 76) berpendapat bahwa motivasi mempunyai tiga fungsi yakni: (1) Mendorong manusia untuk berbuat, sehingga motivasi berfungsi sebagai penggerak atau motor yang melepaskan energi. 
(2) Menentukan arah perbuatan, yakni kearah tujuan yang hendak dicapai. (3) Menyeleksi perbuatan, yakni menentukan perbuatan-perbuatan yang harus dijalankan yang serasi guna mencapai tujuan yang dimaksud dengan mengesampingkan perbuatan-perbuatan yang tidak bermanfaat. Selain itu motivasi juga dapat berfungsi sebagai pendorong usaha dan pencapaian prestasi (Sardiman, A.M, 2001: 83).

Seseorang melakukan suatu usaha karena adanya motivasi. Motivasi yang kuat dalam pembelajaran akan membawa hasil yang baik. Adanya usaha yang tekun, rajin dan berjuang tanpa menyerah yang didasari oleh motivasi, maka siswa akan memperoleh hasil yang baik, sebab intensitas motivasi siswa akan sangat menentukan tingkat pencapaian hasil belajar.

c. Faktor-faktor yang Mempengaruhi Motivasi Belajar

Haris Mudjiman (2011: 48) berpendapat bahwa perbuatan belajar, seperti halnya perbuatan-perbuatan sadar dan perbuatan-perbuatan paksaan pada umumnya, selalu didahului oleh proses pembuatan keputusan-keputusan untuk berbuat atau tidak berbuat. Apabila kekuatan motivasinya cukup kuat, ia akan memutuskan untuk melakukan perbuatan belajar. Sebaliknya, apabila kekuatan motivasinya tidak cukup kuat, ia akan memutuskan untuk tidak melakukan perbuatan belajar. Selanjutnya beliau berpendapat sekurang-kurangnya ada delapan faktor yang diperkirakan berpengaruh terhadap pembentukan motivasi belajar yaitu: (1) Faktor pengetahuan tentang kegunaan belajar, (2) Faktor kebutuhan untuk belajar, (3) Faktor kemampuan melakukan kegiatan belajar, (4) Faktor kesenangan terhadap ide melakukan kegiatan belajar, (5) Faktor pelaksanaan kegiatan belajar, (6) Faktor hasil belajar, (7) Faktor kepuasan terhadap hasil belajar, dan (8) Faktor karakteristik pribadi dan lingkungan terhadap proses pembuatan keputusan. Hubungan hipotesis ke delapan faktor tersebut disajikan secara skematis berikut ini. 


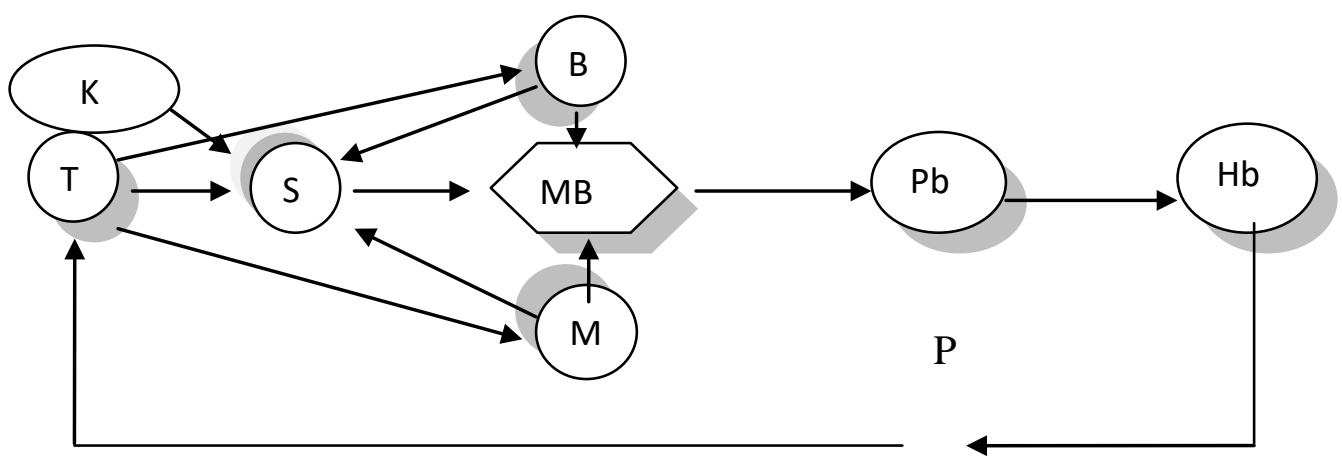

Gambar 1: Model Pengembangan Motivasi Belajar menurut Haris Mudjiman

\section{Keterangan:}

$\mathrm{T}$ : Pengetahuan

B : Kebutuhan

M : Kemampuan

$\mathrm{S}$ : Kesenangan

$\mathrm{Pb}$ : Pelaksanaan kegiatan belajar

Hb: Hasil Belajar

$\mathrm{P}$ : Kepuasan

K : Karakteristik pribadi dan lingkungan

\section{d. Motivasi ARCES (ARCES Motivation)}

Dalam dunia pendidikan ada berbagai macam teori motivasi yang dapat dikembangkan. Salah satu teori motivasi tersebut adalah teori ARCS (ARCS Motivation). John M. Keller dalam Reigeluth (1983) menyusun seperangkat prinsip-prinsip motivasi yang dapat diterapkan dan dikembangkan dalam proses pembelajaran yang di sebut dengan motivasi ARCS (ARCS Motivation. Keller dalam Driscoll (1994: 314) berpendapat bahwa guru perlu memberi motivasi kepada siswa. Atau dalam kalimat lain, munculnya motivasi belajar dalam diri siswa, bukan hanya menjadi tanggung jawab siswa itu sendiri, tetapi guru mempunyai tanggung jawab juga. Menurut Andreas Kosasih (2014: 62) teori motivasi ARCS belumlah cukup, dan ARCS perlu disempurnakan menjadi teroi motivasi ARCES. Oleh sebab itu, prinsip-prinsip motivasional ARCES (ARCES Motivation) perlu diterapkan dan dikembangkan dalam proses pembelajaran. Motivasi ARECS (ARCES Motivation) dapat diurakan sebagai berikut: 
1. Penerapan $A=$ attention (perhatian)

Dalam kegiatan belajar siapapun harus memiliki atensi dan keinginan tentang suatu materi. Oleh sebab itu dalam diri siswa perlu ditumbuhkan adanya pertanyaan reflektif "mengapa saya harus belajar tentang ini?”. Dalam hal ini motivasi siswa tumbuh dan bangkit antara lain karena dorongan ingin tahu. Rasa ingin tahu perlu mendapatkan rangsangan, sehingga siswa akan memberikan perhatian. Perhatian tersebut akan terpelihara selama proses pembelajaran berlangsung, atau bahkan akan tahan lebih lama lagi. Rasa ingin tahu dapat dirangsang melalui cara-cara baru, cara aneh, cara lain dengan yang sudah ada.

Perhatian adalah pemrosesan secara sadar sejumlah kecil informasi dari sejumlah besar informasi yang tersedia. Informasi didapatkan dari penginderaan, ingatan maupun proses kognitif lainnya. Proses atensi membantu efisiensi penggunaan sumberdaya mental yang terbatas yang kemudian akan membantu kecepatan reaksi terhadap rangsang tertentu' Groover menyebutkan bahwa faktor yang memengaruhi persepsi dan ingatan adalah perhatian (attention). Perhatian merupakan aktivitas menjaga sesuatu tetap dalam pikiran yang membutuhkan kerja mental dan konsentrasi. Terdapat 5 jenis perhatian, yaitu: (a) Perhatian selektif (Selective Attention), (b) Perhatian terfokus (Focused Attention), (c) Perhatian terbagi (Divided Attention), (d) Perhatian yang terus menerus (Sustained Attention), (e) Kurang perhatian (Lack of Attention).

Strategi untuk merangsang minat dan perhatian siswa dengan cara sebagai berikut: (1) Gunakan metode pembelajaran yang bervariasi, (2) Gunakan media untuk melengkapi penyampaian bahan kajian, (3) Gunakan teknologi sesuai dengan tingkat perkembangan siswa, (4) Gunakan humor bilamana diperlukan, (5) Gunakan peristiwa nyata untuk memperjelas konsep yang diutarakan, (6) Libatkan siswa.

2. $\quad$ Penerapan $R=$ Relevance $($ relevansi $=$ kegunaan)

Secara umum, arti dari relevansi adalah kecocokan. Relevan adalah bersangkut paut, berguna secara langsung (kamus bahasa Indonesia). Relevansi berarti kaitan, hubungan (kamus bahasa Indonesia). Menurut Green (1995: 16), relevansi ialah sesuatu sifat yang terdapat pada dokumen yang dapat membantu pengarang dalam memecahkan kebutuhan akan informasi. Dokumen dinilai relevan bila dokumen tersebut mempunyai topik yang sama, atau berhubungan dengan subjek yang diteliti (topical relevance). Pada berbagai tulisan mengenai relevance, 
topicality (topik) merupakan faktor utama dalam penilaian kesesuaian dokumen. Froelich dalam Green (1995: 16) menyebutkan bahwa inti dari relevance adalah topicality. Joan M. Reitz (2004: 606) mengemukakan bahwa "relevance the extent to which information retrieved in a search of a library collection or other resource, such as an online catalog or bibliographic database, is judged by to user to be applicable to (about) the subject of the query. Pendapat ini menyatakan bahwa relevansi merupakan sejumlah informasi terpanggil dalam sebuah pencarian pada koleksi perpustakaan atau sumber lainnya, seperti catalog online atau basis data bibliografi, dimana informasi yang diberikan sesuai dengan subjek pada query dan relevan dengan kebutuhan pengguna.

Artinya motivasi belajar akan tumbuh dan berkembang apabila siswa mengakui bahwa materi ajar mempunyai manfaat langsung dalam dirinya. Relevansi menunjuk adanya hubungan antara materi ajar dengan kebutuhan dan kondisi siswa. Motivasi siswa akan tumbuh dan terpelihara serta terbangkitkan apabila siswa merasakan apa yang dipelajari memenuhi kebutuhan pribadi, bermanfaat serta sesuai dengan nilai yang diyakini, diperjuangkan dan dipegangnya.

Strategi untuk menunjukkan relevansi antara lain dengan cara berikut: (a) Sampaikan kepada siswa tentang apa yang akan dapat mereka lakukan setelah mempelajari materi. Ini berarti guru harus menjelaskan tujuan pembelajaran. (b) Jelaskan manfaat pengetahuan, ketrampilan, nilai dan sikap yang akan dipelajari, dan bagaimana hal tersebut dapat diaplikasikan dalam kehidupan kelak kemudian hari. (c) Berikan contoh, latihan atau tes yang langsung berhubungan dengan kondisi siswa atau profesi tertentu.

3. Penerapan $C=$ Confidence (kepercayaan diri)

Rasa percaya diri merupakan perpaduan antara keyakinan dan kemampuan dalam menghargai diri sendiri. Kepercayaan diri termasuk dalam ranah psikologi karena berkaitan dengan proses mental yang berpengaruh pada perilaku. Rasa percaya diri berhubungan dengan cara seseorang dalam memandang diri sendiri baik kekuatan maupun kelemahan yang dimiliki.

Adanya rasa percaya diri dalam diri seseorang akan tampak pada caranya bersikap dan berperilaku. Orang yang memiliki rasa percaya diri umumnya menyukai diri sendiri dan senantiasa berpikir positif. Rasa percaya diri tersebut terwujud dalam ekspresi dan gestur tubuh yang tenang. Bahkan rasa percaya diri juga sering tervisualisasi pada penampilan, di mana orang 
dengan kepercayaan diri tinggi tak jarang menampilkan sesuatu yang lain daripada yang lain sehingga terbilang nyentrik. Mereka cenderung tidak ambil pusing dengan pendapat orang lain, tetapi bukan berarti tidak peduli. Orang yang percaya diri lebih berfokus pada keyakinan dan kemampuan membawa diri yang dapat menciptakan rasa nyaman dalam berperilaku yang dibutuhkan untuk memperoleh hasil sesuai yang diharapkan.

Memang banyak faktor yang mempengaruhi tingkat kepercayaan diri seseorang, mulai dari kondisi psikologi, lingkungan, dan lain sebagainya. Meski demikian, rasa percaya diri tidaklah ditentukan oleh gen atau dipengaruhi oleh faktor keturunan. Artinya, rasa percaya diri dapat dibangun dan ditingkatkan. Jika Anda termasuk orang yang sulit untuk membangun rasa percaya diri, ada baiknya mengikuti tips berikut agar dapat membangun rasa percaya diri dengan mudah: (a) pahami prioriras diri, (b) bangun kesadaran diri, (c) bangun identitas diri.

Strategi yang dapat dikembangkan untuk menumbuhkan dan mengembangkan kepercayaan diri adalah sebagai berikut: (a) Meningkatkan harapan siswa untuk berhasil dengan memperbanyak contoh-contoh berhasilnya siswa atau tokoh lain, dengan cara mempersiapkan pembelajaran agar mudah dipahami oleh siswa dengan cara mengurutkan dari materi yang mudah ke materi yang sulit. (b) Menyusun materi ajar ke dalam bagian-bagian yang lebih kecil, sehingga siswa tidak dituntut untuk mempelajari terlalu banyak konsep baru sekaligus. (c) Menyampaikan tujuan pembelajaran dan kriteria tes atau ujian pada awal pembelajaran. Hal ini dilakukan agar dapat membantu siswa mempunyai gambaran yang jelas mengenai apa yang diharapkan. (d) Menggunakan strategi kontrol keberhasilan yang ada dalam diri prserta didik sendiri. (e) Menumbuhkembangkan kepercayaan diri dengan katakata yang mengenakkan siswa. Contoh: kalian telah memahami konsep ini dengan baik, namun demikian masih arus ditingkatkan agar pemahaman kalian semakin sempurna. (f) Memberikan umpan balik yang konstruktif

\section{Penerapan $E=$ Enjoyment (kesenangan/kegembiraan)}

Era globalisasi yang dihadapi pada saat ini telah membawa dampak di berbagai bidang kehidupan, terutama bidang pendidikan. Oleh karena itu hampir seluruh megara berkembang berupaya membenahi pendidikannya, termasuk negara kita Indonesia. 
Rasa senang dalam kegiatan pembelajaran banyak ditentukan oleh keberhasilan belajar pada waktu-waktu sebelumnya. Selain itu rasa senang juga ditentukan oleh hasil analisis cost-benefit perbuatan belajar, serta rasa butuh belajar dan keyakinan bahwa ia akan mempu mencapai tujuan belajar (Haris Mudjiman, 2008: 91).

Enjoyment learning dimaksudkan agar guru mampu menciptakan suasana belajar yang menyenangkan, sehingga siswa dapat memusatkan perhatian secara penuh. Pembelajaran yang menyenangkan merupakan suatu usaha membangun pengalaman belajar siswa dengan berbagai proses untuk mendapatkan pengalaman baru, melalui penciptaan kegiatan belajar yang beragam dan mengkondisikan suasana belajar, sehingga mampu memberikan pelayanan pada berbagai tingkat kemampuan dan gaya belajar siswa, serta siswa lebih terpusat perhatiannya secara penuh.

Sesuatu yang dilakukan dengan rasa senang akan mendatangkan kebahagiaan, kepuasan lahir batin, kenikmatan dalam belajar, keringanan tenaga dan waktu, kesehatan dan semangat belajar. Selain itu, melakukan belajar dengan rasa senang dapat menjadikan badan sehat, menghilangkan stres, menjadi awet muda, memiliki banyak teman, dan lebih menarik dipandang (Das Salirawati, 2018: 41). Pembelajaran menyenangkan artinya adalah pembelajaran yang interaktif dan atraktif, sehingga peserta didik dapat memusatkan perhatian terhadap pembelajaran yang sedang dijalani. Selain itu, pembelajaran yang menyenangkan adalah pembelajaran yang membuat peserta didik tidak takut salah, ditertawakan, diremehkan, dan tertekan. Sebaliknya peserta didik merasa berani berbuat dan mencoba, bertanya, mengemukakan pendapatnya/gagasannya, serta mempertanyakan gagasan orang lain.

Strategi yang dapat ditempuh untuk memunculkan rasa senang belajar antara lain: (a) belajar sambil bermain, (b) belajar dengan bantuan media, (c) belajar dengan bernyanyi. Sementara teknik penerapan joyful learning antara lain sebagai berikut: (a) menciptakan lingkungan belajar tanpa stres (lingkungan belajar yang rileks), (b) mengkaitkan materi pembelajaran dengan kehidupan sehari-hari (kontekstual), (c) menciptakan emosional positif dalam belajar, (d) melibatkan secara sadar semua indera, (e) mengaktifkan otak kanan dan kiri, (f) menggunakan kecanggihan teknologi, (g) menutup pelajaran yang mengesankan dan menimbulkan penasaran. 
Di depan sudah dibahas bahwa bahwa rasa senang terhadap kegiatan belajar banyak ditentukan oleh keberhasilan belajar pada waktu-waktu sebelumnya. Selain itu rasa senang juga ditentukan oleh hasil analisis costbenefit perbuatan belajar, serta rasa butuh belajar dan keyakinan bahwa ia akan mampu mencapai tujuan belajar (Haris Mudjiman, 2008: 91). Oleh sebab itu untuk menumbuhkan rasa senang belajar dapat dilakukan dengan menyadarkan siswa dengan cara: (a) $\mathrm{T}=$ Pengetahuan. Apakah siswa memiliki pengetahuan yang cukup tentang detail perbuatan belajar yang sedang dikembangkan. (b) $\mathrm{B}=$ Kebutuhan. Apakah siswa merasa butuh melakukan kegiatan belajar yang sedang dipertimbangkan, karena kegiatan itu menjanjikan pemenuhan suatu kebutuhan. (c) $\mathrm{M}=$ Kemampuan. Apakah siswa merasa mampu melakukan perbuatan belajar yang sedang dipertimbangkan. (d) $\mathrm{S}=$ Kesenangan. Apakah pembelajar merasa senang dengan ide belajar.

\section{Penerapan $S=$ Satisfaction (kepuasan)}

Belajar harus menghasilkan rasa puas. Sebab rasa puas akan menyokong dan mendorong tumbuhnya keinginan untuk tetap belajar. Joyfull learning akan mengakibatkan succesfull learning, atau sebaliknya succesfull learning akan mengakibatkan Joyfull learning. Keberhasilan dalam mencapai suatu tujuan akan mengakibatkan kepuasan dan siswa/mahasiswa akan termotivasi untuk terus berusaha mencapai tujuan serupa. Untuk meningkatkan dan memelihara motivasi siswa, guru/dosen dapat memberikan penguatan (reinforcement) berupa pujian, pemberian kesempatan atau bahkan kalau mungkin diberi hadiah. Strategi untuk meningkatkan kepuasan antara lain dengan: (a) Menggunakan pujian, (b) Memberikan umpan balik, (c) Memberikan kesempatan kepada siswa/mahasiswa untuk menggunakan atau mempraktekkan pengetahuan yang sudah diperolehnya, (d) Memberi kesempatan kepada siswa/mahasiswa yang menguasai untuk membantu temannya yang belum menguasai, (e) Baik juga kalau guru/dosen membandingkan prestasi siswa/mahasiswa dengan prestasi guru/dosen dengan suatu standar tertentu.

\section{KESIMPULAN}

Memperhatikan harapan dari Kementerian Pendidikan dan Kebudayaan untuk menjadi kampus Merdeka belajar/kampus merdeka dengan ciri belajar di yang lebih otonom dengan kultur pembelajaran yang inovatif dan fleksibel, STKIP Widya Yuwana Madiun yang salah satu misinya (misi pertama): menguasai teori atau konsep secara benar berkaitan dengan Ilmu Pendidikan 
Teologi dan mengembangkannya. Maka dengan mengembangkan model pembelajaran berbasis motivasi ARCES dalam setiap mata kuliah motivasi dosen dan mahasiswa akan terbangun/berkembang dan proses dan hasil belajarnya mahasiswa akan lebih baik.

\section{DAFTAR PUSTAKA}

Aisyah, Eny Nur dkk., 2019, Entrepreneurship Berbasis Model Meaningful Instructional Design. Bandung: PT. Refika Aditama.

Chatib, Munif., 2019, Gurunya Manusia. Bandung: Mizan Media Utama (MMU) Eric, Jensen \& Nickelsen, LeAnn., 2011, Deeper Learning. Jakarta: PT. Indeks. Haris Mudjiman, Y Slamet, St, \& Setiawan, Budi, (2013), “The Developmant of Writing Learning Model Based on the ARCES Motivation for Student of Senior High School”, dalam Journal of Education and Practice Vol 4, No $12,123-129$.

-------. (2014), “The Development of Writing Learning Model Based on the Arces Motivation for Students of Senior High School”, Journal of Education and Learning, Vol.8 (3) pp. 281-290.

-------. 2014, Pengembangan Model Pembelajaran Menulis Berasis Motivasi ARCES untuk Siswa SMA. (Disertasi) Surakarta: Program Pascasarjana Universitas Sebelas Maret.

-------. 2019, Belajar dan Pembelajaran. Salatiga: Widya Sari Press.

Joenaidy, Abdul Muis., 2019, Konsep dan Strategi Pembelajaran di Era Revolusi Industri 4.0. Yogyakarta: Laksana.

Joyce \& Weil., 2000, Models of Teaching. New Jersey: Prentice-Hall Inc.

Keller, JM., 1987, Development and Use of The ARCS Models of Motivational Design. J. instr. Dev. New Jersey.

Kementerian Pendidikan dan Kebudayaan RI., 2019, Merdeka Belajar: Kampus Merdeka. Jakarta: Direktorat Jenderal PendidikanTinggi Kemendikbud RI.

Kosasih, Andreas, \& Angkoro, R., 2007, Optimalisasi Media Pembelajaran. Jakarta: PT. Grasindo.

Mudjiman, Haris., 2008, Manajemen Pelatihan Berbasis Belajar Mandiri. Yogyakarta: Pustaka Pelajar.

-------. 2011, Belajar Mandiri. Surakarta: UPT Penerbitan dan Percetakan UNS (UNS Press) dan Lembaga Pengembangan Pendidikan (LPP) UNS.

Russel, James D., 2004, Moduler Instruction. Minneapolist: Burgess Publishing Company.

Salirawati, Das., 2018, Smart Teaching Solusi Menjadi Guru Profesional. Jakarta: Bumi Aksara. 
Sulistyorini, Sri., 2007, Model Pembelajaran IPA di Sekolah Dasar. Semarang: Fakultas Ilmu Pendidikan, Jurusan Pendidikan Guru Sekolah Dasar Universitas Negeri Semarang (UNNES) dengan Tiara Wacana.

Trianto., 2010, Model Pembelajaran Terpadu Konsep, Strategi, dan Implementasinya dalam Kurikulum Tingkat Satuan Pendidikan. Jakarta: Bumi Aksara. 